\title{
Chapter 2. Early-Line Potato Variety Trial, $2006^{1}$
}

\author{
C.M. Hutchinson, and Doug Gergela ${ }^{2}$
}

General Comments: Potato clones in this trial are new to the variety evaluation program. At this stage, seed supplies are usually limited. To maintain a replicated trial with a small seed lot, plot size is reduced to twelve seed pieces. This is a mixed trial with round white, red, and russet varieties.

Planting Information

\begin{tabular}{|l|l|}
\hline Planting Site & PSREU - CityHastings Farm, Hastings, FL \\
\hline Planting Date & January 31,2006 \\
\hline Vine Kill Date & April 28, 2006 \\
\hline Harvest Date & May 15, 2006 \\
\hline Season Length & 87 days planting to vine kill; 104 days planting to harvest \\
\hline Fertilizer Program & preplant, 100-43-86 lb/A; sidedress, 65-0-56 lb/A (2 appl.) \\
\hline Irrigation Program & seepage \\
\hline
\end{tabular}

Experimental Design

Number of Varieties 6 (Standard: Atlantic)

Number of Clones 88

Within Row Spacing

Between Row Spacing 8 in $(20 \mathrm{~cm})$

Replications 40 in $(102 \mathrm{~cm})$

Plot Size 3

Production Statistics

Early Vigor Ratings
Highest Total Yield $8 \mathrm{ft}(2.4 \mathrm{~m})$ 41 days after planting

Highest Marketable Yield ND8331 Cb-3 (550 cwt/acre or 61.6 MT/ha)

Best Appearance Rating ND8331Cb-3 (414 cwt/acre or 46.4 MT/ha)

LaChipper, AF3318-13, AF3327-27 and B2529-3 (7.0, good to excellent)

1. This document is HS1086, one of a series of the Horticultural Sciences Department, Florida Cooperative Extension Service, Institute of Food and Agricultural Sciences, University of Florida. Original publication date March, 2007. Visit the EDIS Web Site at http://edis.ifas.ufl.edu.

2. Chad M. Hutchinson, Associate Professor, Doug Gergela, Sr. Biological Scientist, Horticultural Sciences Department, Cooperative Extension Service, Institute of Food and Agricultural Sciences, University of Florida, Gainesville, 32611.

The use of trade names in this publication is solely for the purpose of providing specific information. UF/IFAS does not guarantee or warranty the products named, and references to them in this publication does not signify our approval to the exclusion of other products of suitable composition. All chemicals should be used in accordance with directions on the manufacturer's label. Use pesticides safely. Read and follow directions on the manufacturer's label.

The Institute of Food and Agricultural Sciences (IFAS) is an Equal Opportunity Institution authorized to provide research, educational information and other services only to individuals and institutions that function with non-discrimination with respect to race, creed, color, religion, age, disability, sex, sexual orientation, marital status, national origin, political opinions or affiliations. U.S. Department of Agriculture, Cooperative Extension Service, University of Florida, IFAS, Florida A. \& M. University Cooperative Extension Program, and Boards of County Commissioners Cooperating. Larry Arrington, Dean 


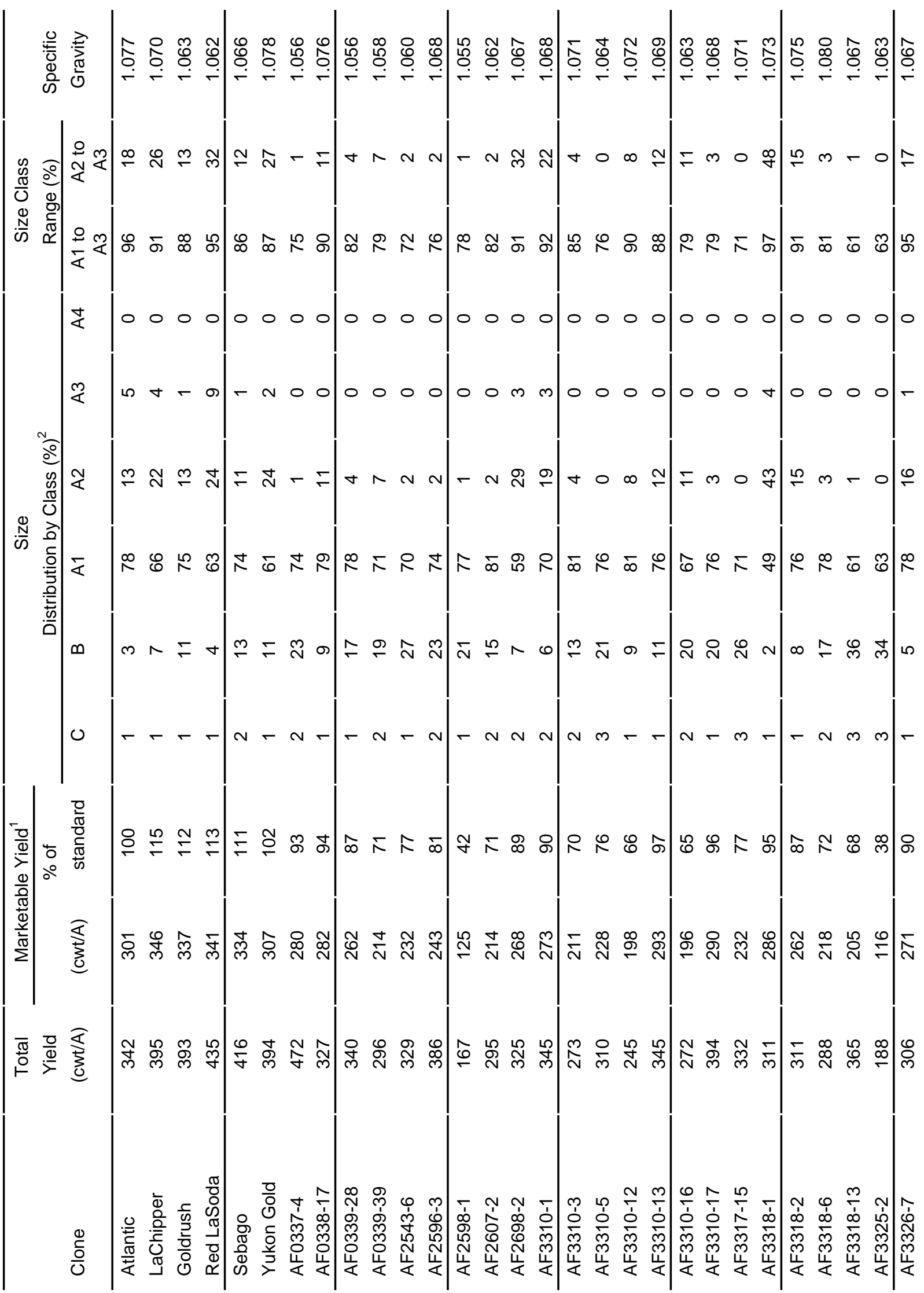




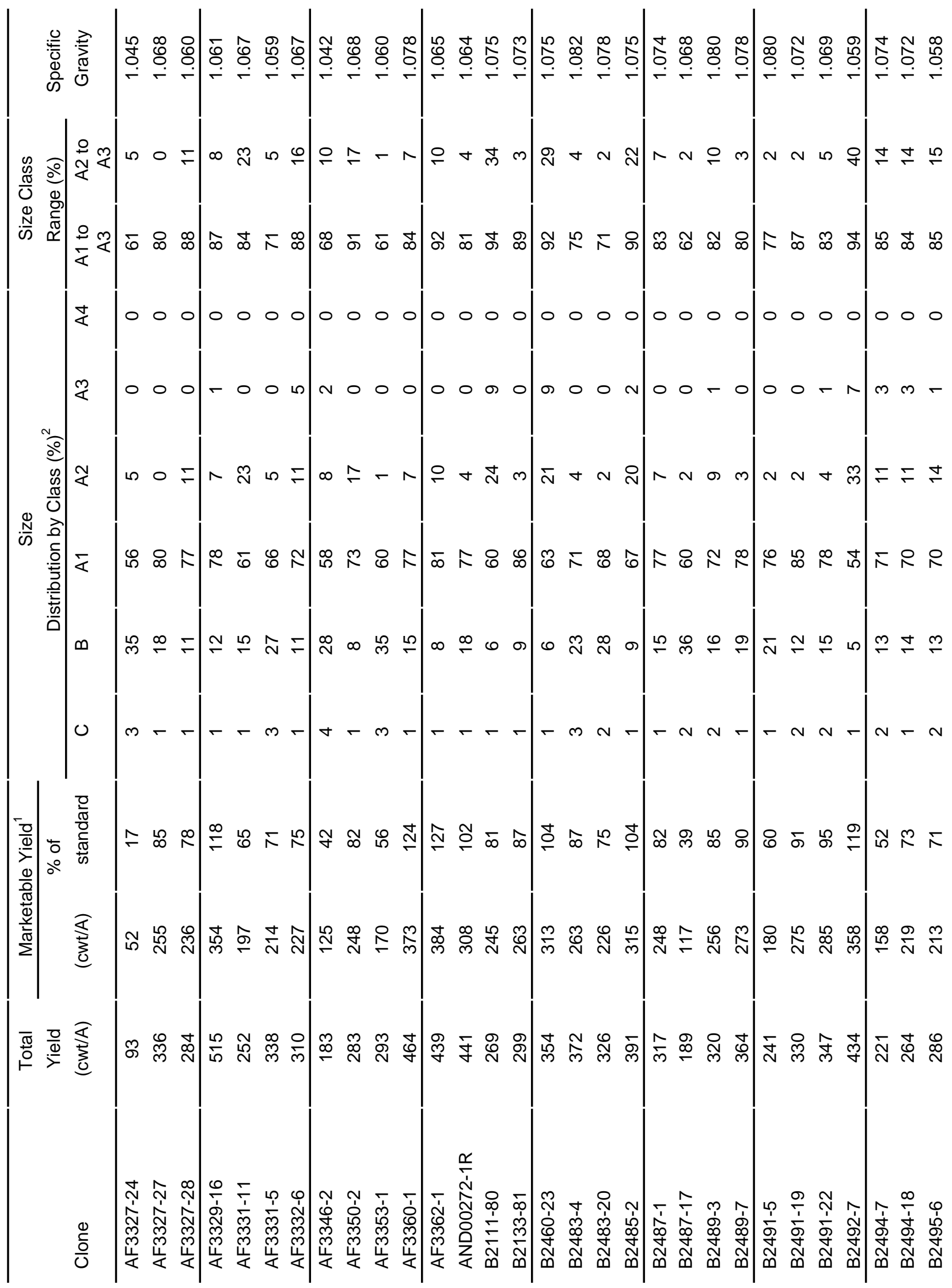




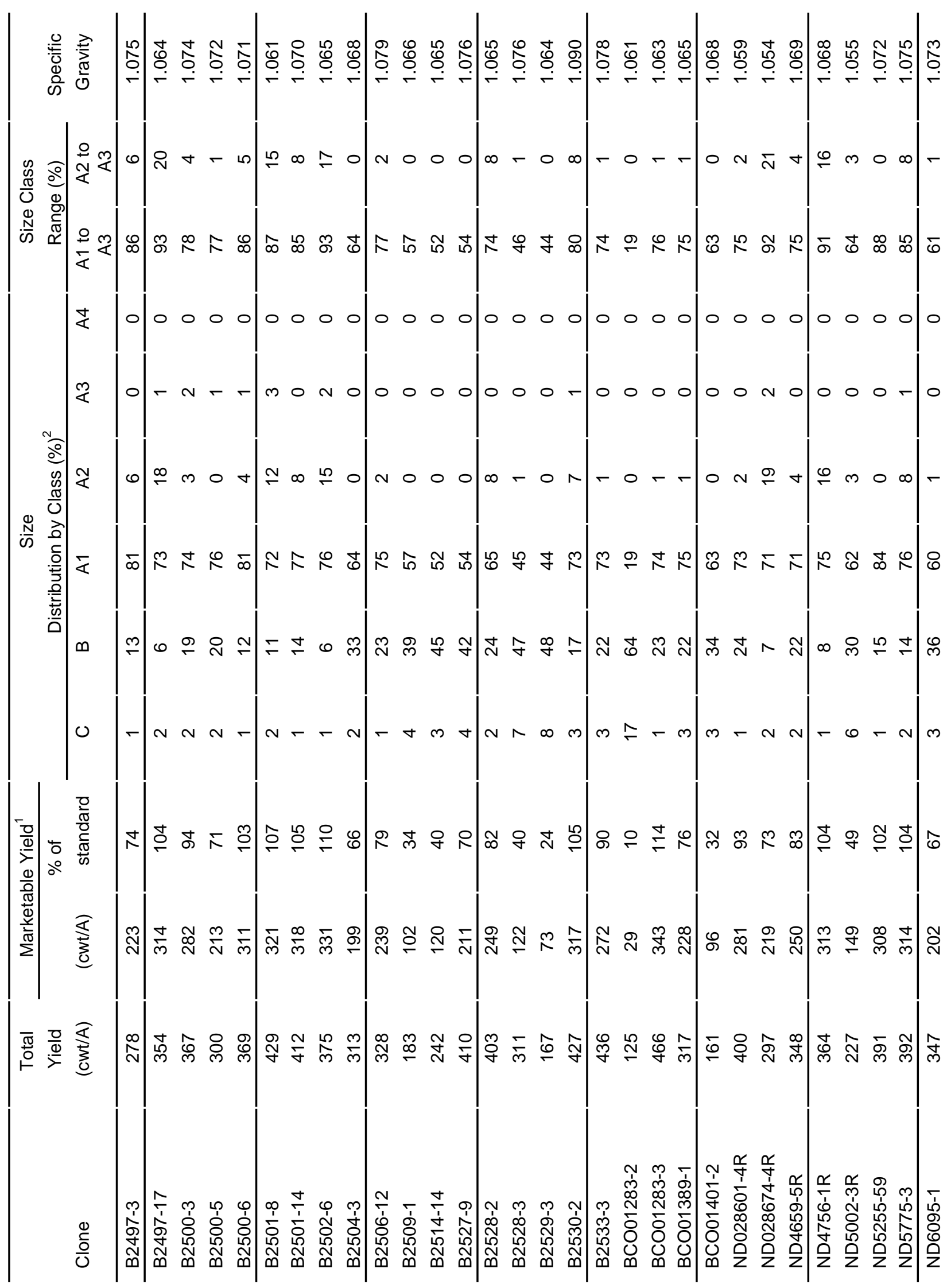




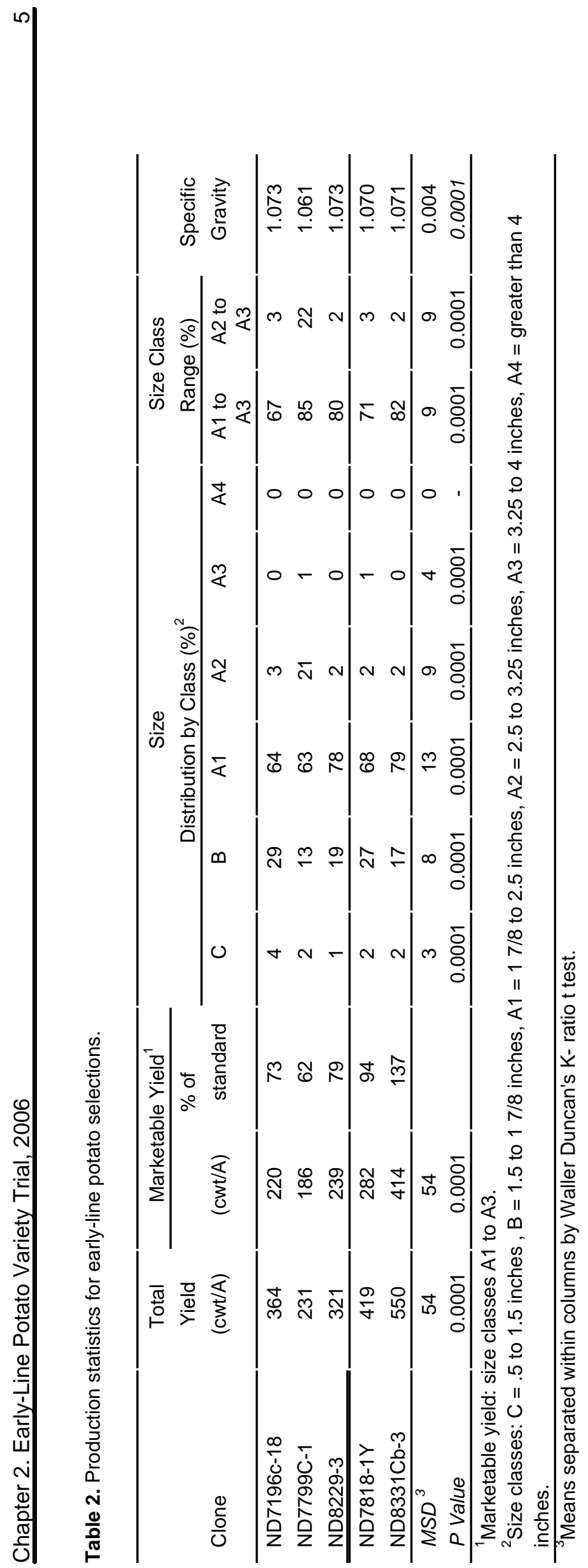



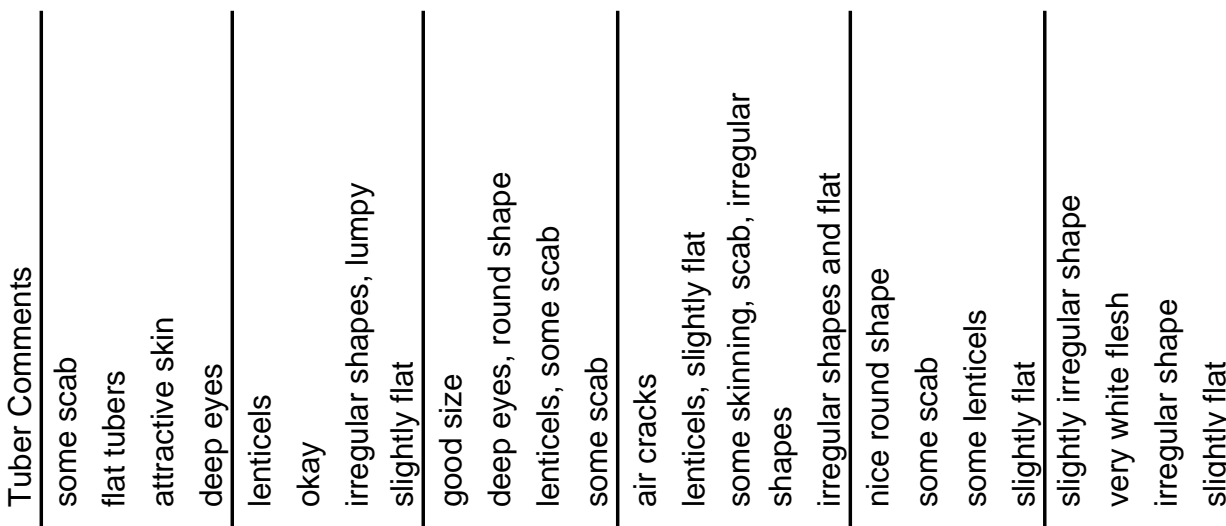

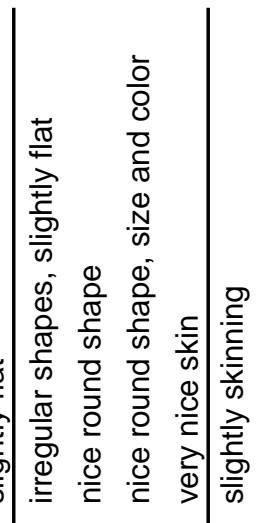

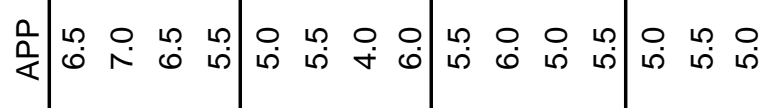

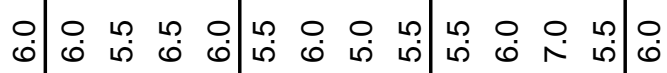
س $n$ n

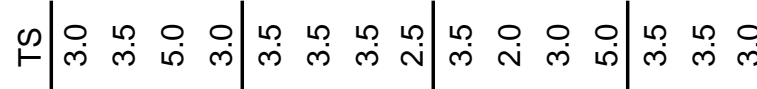
ம

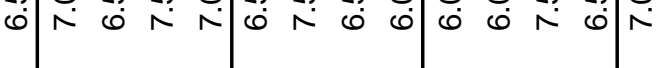

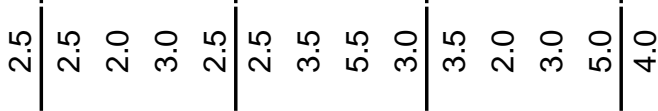
ما 0) W

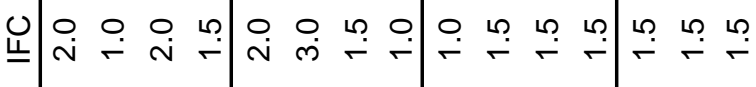


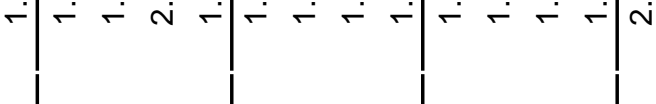

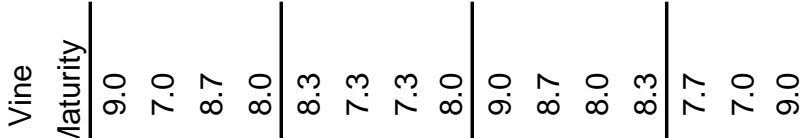

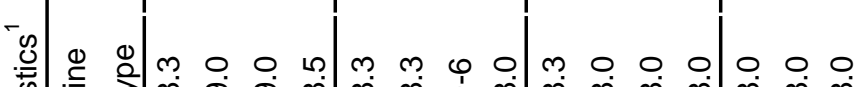

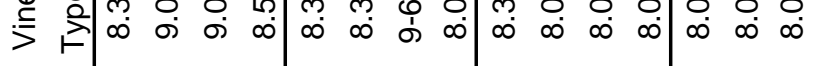
0
0
$\frac{\pi}{0}$
$\frac{\pi}{0}$
0
$\frac{5}{3}$
0
0
$\frac{0}{0}$
$\frac{\pi}{0}$

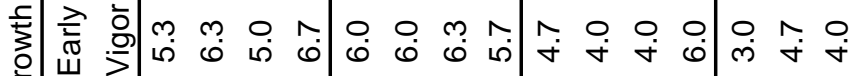
の .

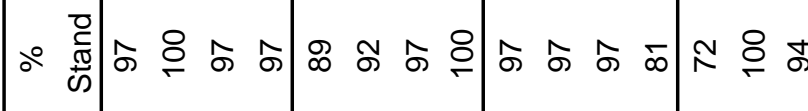

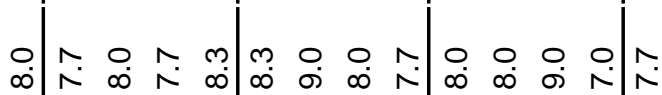
के के


实 c 变

-

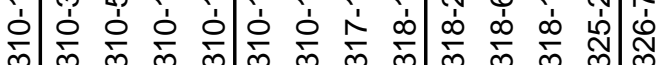

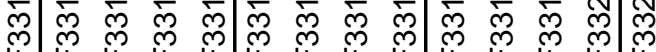

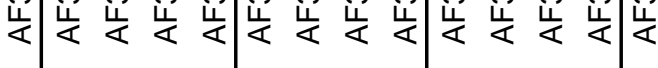




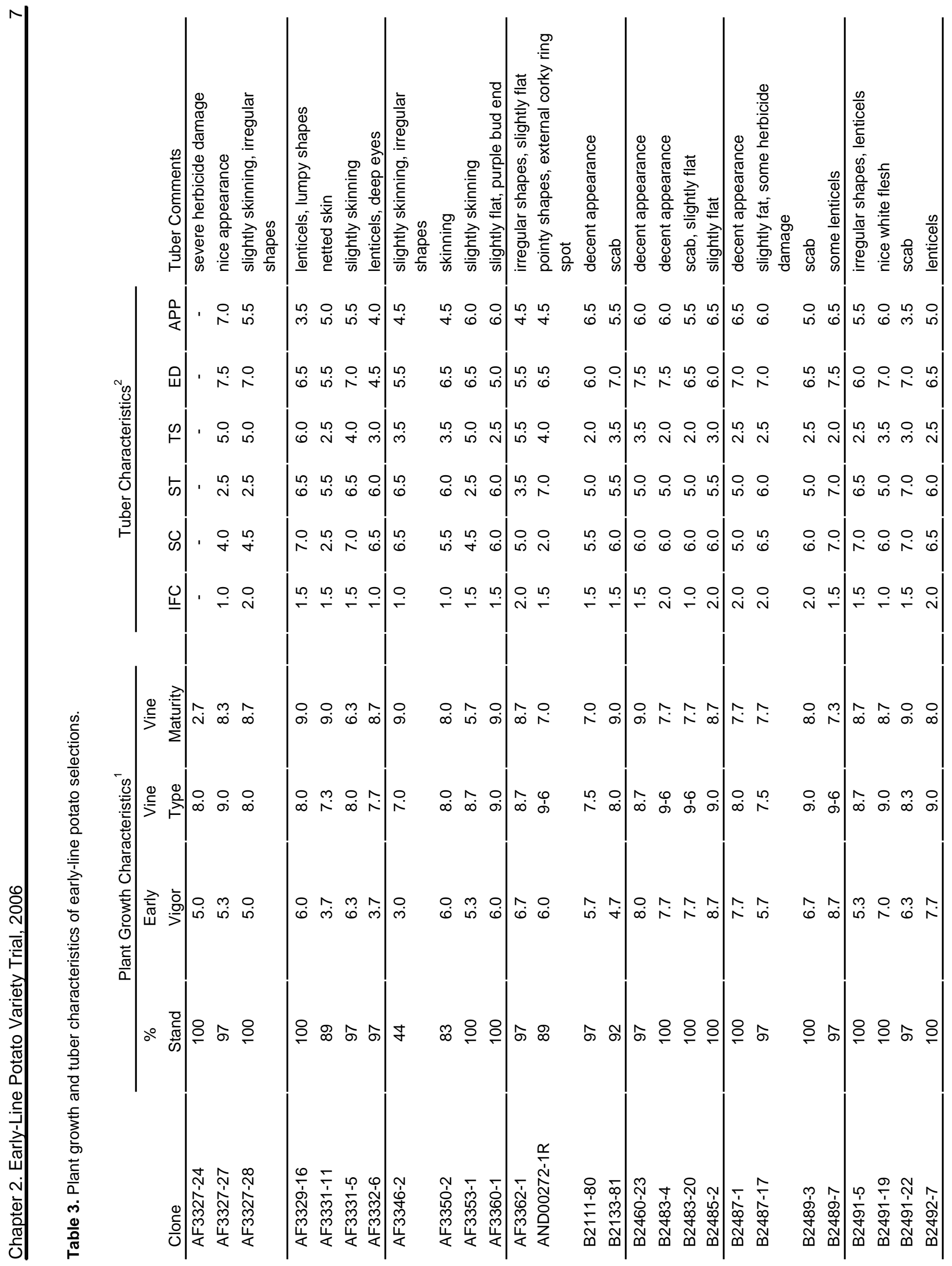









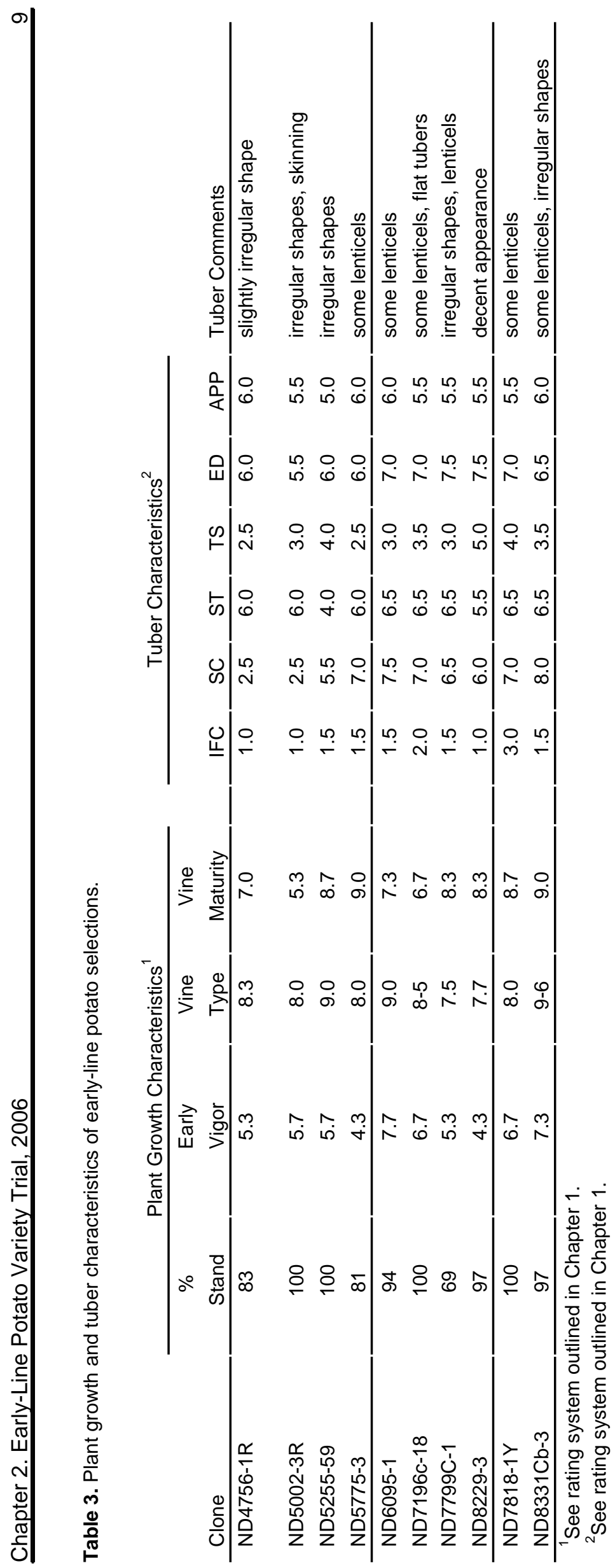




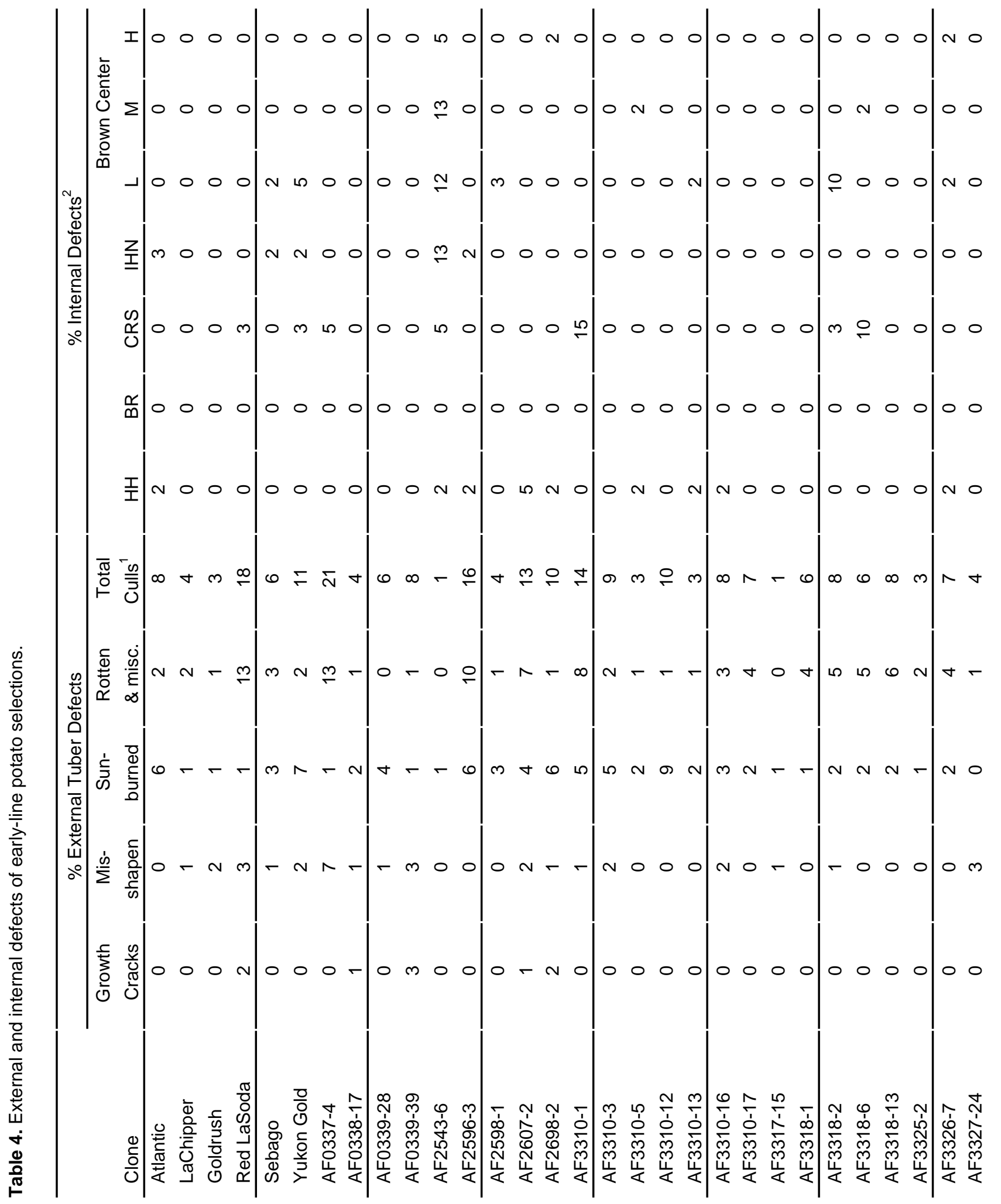




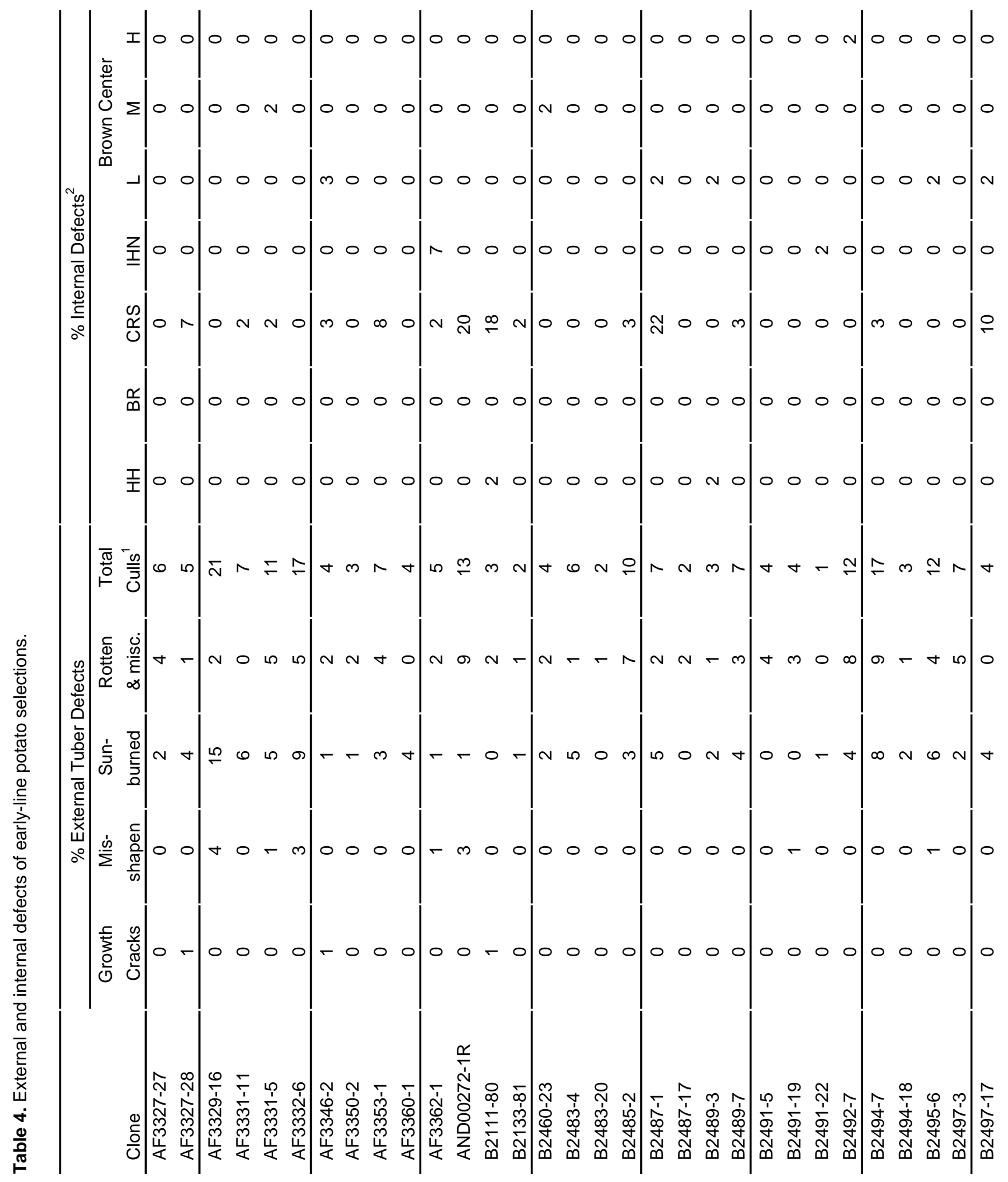







Archival copy: for current recommendations see http://edis.ifas.ufl.edu or your local extension office.

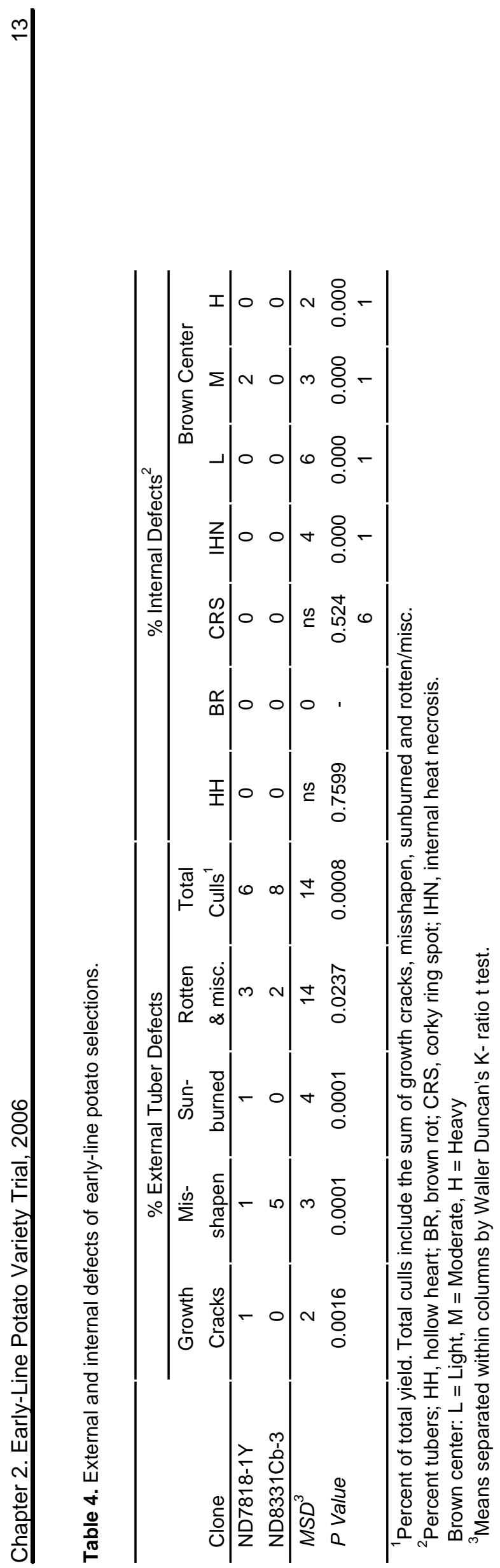

